\title{
A SYSTEMIC-FUNCTIONAL AND CRITICAL DISCOURSE ANALYSIS OF ONLINE MATCHMAKING
}

\author{
(Uma análise sistêmico-funcional e crítica do discurso de \\ matchmaking on-line)
}

Fábio Alexandre Silva Bezerra ${ }^{1}$

(Universidade Federal de Santa Catarina UFSC/)

\begin{abstract}
In contemporary society, many are the genres and media used to create social bonds among people of the most different background, ages, classes and sexual orientations. In this context, the internet is occupying an ever increasing space in people's everyday lives. This paper aims to demonstrate how language can be used to construe representations of the world that position people socially. Although the discourse of modern days seems to celebrate people's individual life choices, overall results of the transitivity (Halliday \& Matthiessen, 2004; Martin; Matthiessen \& Painter 2010) and discourse analysis (Caldas-Coulthard, 1997; Chouliaraki \& Fairclough, 1999, Fairclough, 1989; Fairclough \& Wodak, 1999; van Dijk, 1997) show that people are actually stimulated to find partners by carrying out concrete material actions. Additionally, and maybe contradictorily, the same people are expected to entrust abstract systems (Giddens, 1991) with the responsibility of finding these partners, thus revealing that the new era has impinged significant changes on relationships of intimacy.
\end{abstract}

Keywords: contemporary society, social bonds, language, discourse, abstract systems

1. Fábio Bezerra é especialista em 'Linguística Aplicada ao Ensino de Línguas Estrangeiras' (UFPB) e mestre em 'Língua Inglesa e Literatura Correspondente' (UFSC). Atualmente, está em processo de finalização de tese de doutoramento em 'Língua Inglesa e Linguística Aplicada' na UFSC (CNPq Processo $n^{\circ}$ 142547/2008-5), em cotutela com o 'PhD in Linguistics' da University of Sydney. Como membro do NUPDiscurso (UFSC), desenvolve pesquisas com base na Linguística Sistêmico-Funcional, na Análise Crítica do Discurso, na Multimodalidade e em Estudos de Gênero Social. Entre seus principais interesses de pesquisa, destaca-se o estudo das representações de gênero social na mídia, especialmente na TV, em filmes e em revistas. 


\section{RESUMO}

Na sociedade contemporânea, muitos são os gêneros e meios utilizados para criar laços sociais entre as pessoas das mais diferentes formações, idades, classes sociais e orientações sexuais. Nesse contexto, a internet está ocupando um espaço cada vez maior na vida cotidiana das pessoas. Este trabalho visa demonstrar como a linguagem pode ser usada para construir representações do mundo que posicionam as pessoas no âmbito social. Apesar de o discurso dos dias modernos parecer celebrar as escolhas dos individuos, os resultados gerais da análise de transitividade (Halliday \& Matthiessen, 2004; Martin; Matthiessen \& Painter 2010) e do discurso (Caldas-Coulthard, 1997; Chouliaraki \& Fairclough, 1999, Fairclough, 1989; Fairclough \& Wodak, 1999; van Dijk, 1997) evidenciam, na verdade, que as pessoas são estimuladas a encontrar parceiros por meio de ações materiais concretas. Ademais, e talvez contraditoriamente, espera-se que essas mesmas pessoas confiem a sistemas abstratos (Giddens, 1991) a responsabilidade de encontrar esses parceiros, revelando que a nova era tem causado mudanças significativas nas relações de intimidade.

Palavras-chave: sociedade contemporânea, laços sociais, linguagem, discurso, sistemas abstratos

\section{Introduction}

In contemporary society, many are the genres and media used to create social bonds among people of the most different background, ages, classes and sexual orientations. Among the media used for this purpose, the internet is occupying an ever increasing space in people's everyday lives. Therefore, being a critical reader has never been so important as today, especially for the fact that, through the internet, people are faced with a great amount of information which may or may not be true.

Through the use of language, not only are social bonds created, but also relationships of power and ideologies are (re)shaped. It is precisely this constitutive aspect of language that is the focus of the analysis of Text 1 proposed in this paper. The text is an extract from the opening page of the internet site Yahoo! Personals, where information is given on why people should use their online matchmaking services. 
Even though the text is short, it has been sufficiently rich and thought-provoking for the discussion of how language can be used to create representations of the world according to specific social and institutional agendas, which is precisely one of the main goals in the critical work afforded by analysis that uses notions from systemicfunctional grammar and critical discourse analysis.

\section{Online Personals}

You deserve a matchmaker to find love. At Yahoo! Personals -- your dedicated matchmaking online dating site for great dating services -we believe that if you put yourself out there, you'll meet singles you're looking for -- single men, single women, local singles, even a love match. By taking a personal approach to personal ads, you can find a date and find singles for Christian dating, Jewish dating, Asian dating, black dating, gay dating, or senior dating. With our matchmaking capabilities, you can find that unique person who gets what you're all about, quirks and all. That person who says what you were about to say, who isn't mortified when you make a social blunder, whose scent you'd like to bottle, and whose smile you'd like to wake up to every day. That's why we give you an audience filled with local singles, the tools to find and meet single women and single men, and lots of features that help you find your love match. With Personals as your matchmaker, you can find the kind of first date that leads to second dates and beyond. You still might meet the love of your life at a coffeehouse or gas station. But with Yahoo! Personals, instead of sitting around waiting for that to happen, you'll be getting dates from online dating and having a fabulous time.

Text 1: extract from Yahoo! Personals at http://personals.yahoo.com

\section{Theoretical Foundation}

The constitutive nature of language is vastly described and explored in Systemic Functional Grammar (SFG) (Halliday \& Matthiessen, 2004), according to which language is understood as a system of choices that are made to represent the world around and within us (ideational meanings), to forge relationships (interpersonal 
meanings) and to create coherent and cohesive texts (textual meanings). Therefore, the focus of systemic-functional theory is on "paradigmatic relations - on what you say in relation to what you could have said" (Martin, 2001: 151).

Halliday (1999) stresses the importance of focusing on language use instead of seeing language as solely a system of abstract rules. Thus, for the author, any study of language use must include its social and cultural aspects. Bloor and Bloor (1995: 4) also see contextual information as an indispensable element in analysis, as "we have to remember that [the text] was originally produced as language within a communicative event”. These contextual parameters have three defining components: they are "the underlying social activity, the person or 'voices' involved in that activity, and the particular functions accorded to the text within it" (Halliday, 1999: 10), i.e. field of discourse, tenor of discourse and mode of discourse, respectively.

Since the focus of the analysis in the present paper is on how language is used to create specific representations of the world, only the field of discourse is addressed, as it concerns ideational meanings precisely. The ideational metafunction is realized by the system of transitivity, according to which a clause is a way of representing reality. In this system, each clause is analyzed in relation to the processes realized by the verbs or verbal groups it contains, the participants involved in the process and the circumstances associated with the process. Halliday and Matthiessen (2004) describe the following process types: Material, Mental, Behavioral, Verbal, Existential and Relational. Even though Behavioral and Existential processes were not found in Text 1, they are explained below and examples from Bezerra (2008) are used to illustrate them.

Material processes refer to verbs or verbal groups that describe concrete actions or happenings that cause change in the material world (Martin; Matthiessen \& Painter, 2010), e.g.:

\begin{tabular}{|l|l|l|l|}
\hline $\begin{array}{l}\text { By taking a personal approach to } \\
\text { personal ads, }\end{array}$ & you & can find & a date \\
\hline Circ: manner & Actor & Pr: MATERIAL & Goal \\
\hline
\end{tabular}


Mental processes refer to thoughts and feelings, i.e. our inner world of cognition, desideration, emotion and perception, e.g.:

\begin{tabular}{|l|l|l|}
\hline $\begin{array}{l}\text { At Yahoo! Personals - your dedicated matchmaking } \\
\text { online dating site for great dating services - }\end{array}$ & we & believe \\
\hline Circ: location: place & Senser & Pr: MENTAL \\
\hline
\end{tabular}

Verbal processes are realized by verbs or verbal groups that realize the act of saying something in its most varied forms, even metaphorically, e.g.:

\begin{tabular}{|l|l|l|l|}
\hline That person & {$[$ [who } & says & $\begin{array}{l}\text { what you were about to } \\
\text { say, }\end{array}$ \\
\hline Goal & Sayer & Pr: VERBAL & Verbiage \\
\hline
\end{tabular}

Relational processes construe relationships between the participants of the clause by assigning them with values or attributes, e.g.:

\begin{tabular}{|l|l|l|}
\hline who & isn't & mortified \\
\hline Carrier & Pr: RELATIONAL & Attribute \\
\hline
\end{tabular}

Behavioral processes share elements from Material and Mental processes, i.e. they also concern actions, but these are necessarily carried out by conscious beings.

\begin{tabular}{|l|l|l|}
\hline I & watched & people leaving church, \\
\hline Behaver & Pr: BEHAVIORAL & Scope \\
\hline
\end{tabular}

Existential processes are like Relational processes in that "they construe a participant involved in a process of being, but differ from relational ones in that there is only one participant" (Martin; Matthiessen \& Painter, 2010: 108), e.g.: 


\begin{tabular}{|l|l|l|}
\hline In life, & there are & all sorts of wake-up calls, \\
\hline Circ: place & Pr: EXISTENTIAL & Existent \\
\hline
\end{tabular}

However, Ravelli (2000: 37) argues that "a functional analysis is not simply a question of labelling; the labels reflect a semantic and grammatical interpretation of a text”. Therefore, one should always have in mind that the categorization of process types is always a matter of interpretation, i.e. although there are criteria to determine to which processes certain verbs or verbal groups refer, there will be cases in which the line between one process and another is subtle.

There are two more elements in the clause that are described by the system of transitivity: the participants and the associated circumstances. Participants "are the entities who are represented in the process, people, objects, actions, which are realized by the nominal group" (Heberle, 1997: 102). By identifying the participants in a clause, one can, for instance, "note general characteristics, such as whether they are concrete or abstract; if human, whether female or male, and so on" (Ravelli, 2000: 36). Each process type has its specific participants: a) Material processes: actor, goal, client/recipient and scope; b) Mental processes: senser and phenomenon; c) Verbal processes: sayer, verbiage, target and receiver; d) Relational processes: carrier and attribute / token and value; e) Behavioral processes: behaver, scope and behavior; f) Existential processes: existent.

Circumstances are realized by adverbs, adverbials or prepositional phrases, "accompanying the different processes and participants [in order to] give support (...) or add information” (Heberle, 1997: 154) to what is represented in the clause. The circumstantial elements of the clause might construe: location (time and place), extent, manner, cause, contingency, accompaniment, role, matter and angle.

Even though the analysis afforded by using the system of transitivity in SFG can offer insightful material for critical analysis, it is limited to the level of the clause. In order to expand the results of the transitivity analysis to the level of discourse, which may offer a more global understanding of the text, one must make use of theory that 
allows for the explanation of "how a text relates to the social processes within which it is located" (Halliday, 1999: 10) - and this is where Critical Discourse Analysis (CDA) enters the page.

In his book The Consequences of Modernity, Giddens (1991: 114) discusses the changes that this new era has impinged on relationships of intimacy. One of his basic premises is that the element of trust in personal relationships has been somewhat displaced by trust in abstract systems, since "( $\mathrm{t}$ )rust in abstract systems provides for the security of day-to-day reliability". Thus, this may explain why a growing number of people resort to online services to meet people. It is arguably much easier to trust this abstract system, with all its tools and possibility of secrecy, than trust someone in person. The online matchmaking service seems to bridge the gaps between people who are looking to meet for different purposes, but offering something which personal encounters may not at first: the chance to build trust through a previous scrutiny of the candidate's profile.

What I aim to demonstrate with the result of the analysis is that people should be critical not only when analyzing other people's personal ads, but also when faced with the first step of deciding whether or not to sign up to this kind of service. This is why this paper focuses on the text used by Yahoo! Personals precisely to entice people into using their services. Therefore, I intend to unveil the social identities, ideologies, power and hegemonic relations construed through the linguistic choices made and the resulting discourses, since "texts are systematically structured and socially organised" (Caldas-Coulthard, 1997: 22).

According to Chouliaraki and Fairclough (1999), some concepts are of major importance in the discussion of discourse: discourse as 'joint action', dialectic, practices, mediated discourse, ideology and identities. The authors further argue that discourse is best understood when analyzed as an integral part of social interactions "dialectically related to discursive and linguistic structures" (ibid: 36).

A very relevant aspect discussed by Chouliaraki and Fairclough (1999) in their experience of rethinking CDA is that of 'mediated discourse'. Considering the new configurations in contemporary 
society, the authors claim that analysis should take into account the advances in technology and the impact this has had in social interactions. For them, "modernity has involved a radical change in the nature of social practices and in the relations between social practices" (ibid: 42), with an increasing 'time-space distantiation', which is a strong characteristic of a globalized world. This mediation of people's interactions through immense distances and across different moments in time by using, for instance, the internet is one of the aspects I aim to discuss by addressing online matchmaking in this paper.

It is precisely when this struggle between what is settled in society and what is new is discussed that the topic of ideology has to come to the foreground. This is why it is important to investigate how language is used to make representations of the world, since, as "such representations help sustain relations of domination within the practice, they are ideological” (Chouliaraki \& Fairclough, 1999: 37). On the other hand, it is also "in social interaction that structures are problematized and contested", thus forging "new social relations, new social identities and new social structures" (ibid: 38 ) - that is the 'generative' quality of social life.

\section{Analysis}

As previously put, the analysis at the textual level is informed by the system of transitivity of SFG (Halliday \& Matthiessen, 2004). Therefore, I now turn to the discussion of the results of the categorization of processes, participants and circumstances found in the clauses in Text 1. Following that, Text 1 is further deconstructed and discussed based on the notions of CDA aforementioned.

Table 1 shows the result of the occurrences of processes in the clauses analyzed from Text 1 . As can be easily noted, the vast majority (70\%) of the processes found are Material. This can be associated with the fact that Text 1 is aimed at convincing potential users to sign up to Yahoo! Personals by constantly calling them into actions, i.e. users are urged to do something in order to change their present relationship 
status. As it is known that Material processes construe representations in terms of changes in the material world, it is an expected result that they are most frequently used.

\begin{tabular}{|l|l|l|l|l|}
\hline \multicolumn{2}{|c|}{} & OCCURRENCES & $\#$ & $\%$ \\
\hline \multirow{2}{*}{ P } & Material & $\begin{array}{l}\text { deserve, find (5), put, meet (2), looking } \\
\text { for, bottle, wake up to, give, getting }\end{array}$ & 14 & $70 \%$ \\
\cline { 2 - 5 } O & Mental & believe, gets & 2 & $10 \%$ \\
\cline { 2 - 6 } C & Behavioral & --- & --- &.-- \\
\cline { 2 - 6 } E & Verbal & says & 1 & $5 \%$ \\
\cline { 2 - 6 } S & Relational & isn't, 's, having & 3 & $15 \%$ \\
\cline { 2 - 6 } S & Existential & --- & --- & $\ldots$ \\
\cline { 2 - 6 } E & TOTAL & & 20 & $100 \%$ \\
S & & & & \\
\hline
\end{tabular}

Table 1 - Occurrences of processes in the clauses analyzed.

In the example below, two instances of Material processes (meet and look for) can be seen. What they have in common with most other Material processes found in Text 1 is that they can be associated with the semantic category of romantic relationships. Users are invited to put themselves out there in order to look for love and eventually find and meet lovers so that they can wake up to their smiles.

\begin{tabular}{|l|l|l|l|l|l|}
\hline you & 'll meet & singles & you & 're looking for & $\begin{array}{l}\text {-- single men, } \\
\text { single women, } \\
\text { local singles, } \\
\text { even a love } \\
\text { match. }\end{array}$ \\
\hline Actor & Pr: MATERIAL & Goal & Actor & Pr: MATERIAL & Goal \\
\hline
\end{tabular}

The frequency of the three other process types found in Text 1 are as follows: Relational (15\%), Mental (10\%) and Verbal (5\%). Even though Relational and Mental processes are far less frequent than Material ones, but not that more frequent than Verbal ones, a pattern 
in what they construe can still be noticed. Verbal processes, however, have no significant impact on the representations construed.

Relational processes, for instance, are used to create a connection between potential users (referred to by the impersonal 'you' all over Text 1) and their possible lovers as well as the kind of fun these meetings might afford. See the examples below:

\begin{tabular}{|l|l|l|l|}
\hline who & isn't & mortified & when you make a social blunder, \\
\hline Carrier & Pr: RELATIONAL & Attribute & Circ: location: time \\
\hline
\end{tabular}

\begin{tabular}{|l|l|l|l|l|l|}
\hline 'll be getting & dates & $\begin{array}{l}\text { from online } \\
\text { dating }\end{array}$ & and & having & $\begin{array}{l}\text { a } \\
\text { fabulous } \\
\text { time. }\end{array}$ \\
\hline $\begin{array}{l}\text { Pr: } \\
\text { MATERIAL }\end{array}$ & Goal & $\begin{array}{l}\text { Circ: location: } \\
\text { place }\end{array}$ & & $\begin{array}{l}\text { Pr: } \\
\text { RELATIONAL }\end{array}$ & Attribute \\
\hline
\end{tabular}

Mental processes are used to 1) express that the internet site believes in finding users a partner and 2) to describe a partner that gets the user's real essence.

\begin{tabular}{|l|l|l|}
\hline $\begin{array}{l}\text { At Yahoo! Personals - your dedicated } \\
\text { matchmaking online dating site for great } \\
\text { dating services - }\end{array}$ & we & believe \\
\hline Circ: location: place & Senser & Pr: MENTAL \\
\hline
\end{tabular}

\begin{tabular}{|l|l|l|l|l|l|l|}
\hline $\begin{array}{l}\text { With our } \\
\text { matchmaking } \\
\text { capabilities, }\end{array}$ & you & can find & $\begin{array}{l}\text { that } \\
\text { unique } \\
\text { person }\end{array}$ & {$[[$ who } & gets & $\begin{array}{l}\text { what you're } \\
\text { all about, } \\
\text { quirks and } \\
\text { all.]] }\end{array}$ \\
\hline Circ: manner & Actor & $\begin{array}{l}\text { Pr: } \\
\text { MATERLAL }\end{array}$ & Goal & Senser & $\begin{array}{l}\text { Pr: } \\
\text { MENTAL }\end{array}$ & Phenomenon \\
\hline
\end{tabular}

Since the dynamic participants found in Text 1 are mostly represented by the impersonal 'you', there is no need to discuss 
variation in this construal. They all refer to single men and women in general. Passive participants, on the other hand, present variation between the categories of 'human' and 'others'. Like Hasan (1985), I use the term 'passive', but in a simplified manner. When I refer to a participant as 'passive', it means that it is the receiving end of the clause. The term 'others', in Table 2, includes any participant which is not a human being, ranging from feelings and places to objects and the like.

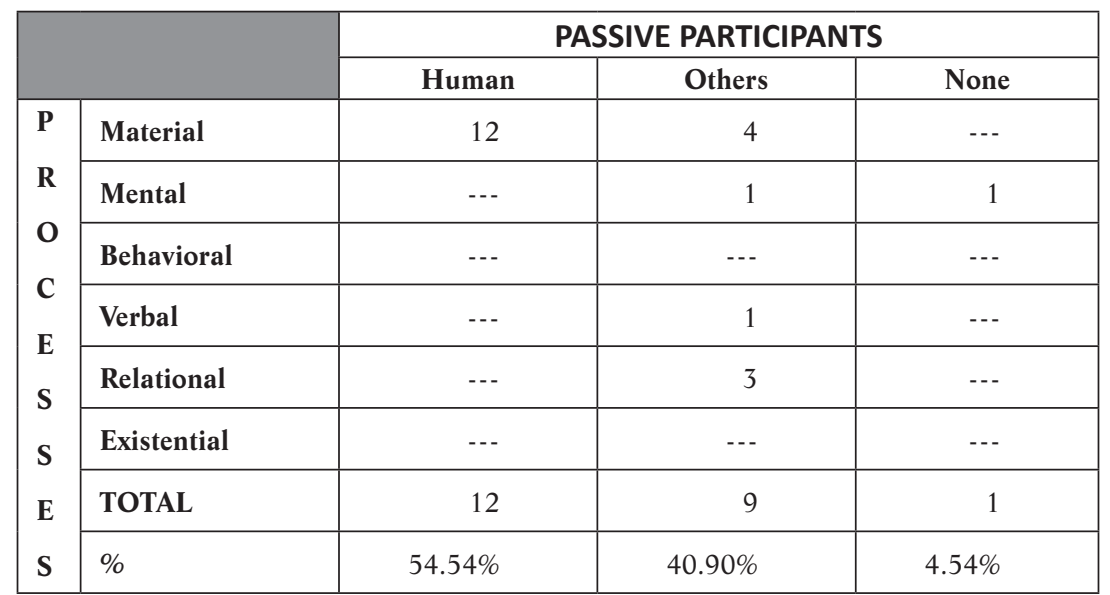

Table 2 - Occurrences of passive participants and the processes in which they are involved.

Interestingly, all passive participants that are human (54.54\%) are involved in Material processes. This shows that the potential user is construed as performing material actions that are directed at future partners. See the following examples:

\begin{tabular}{|l|l|l|l|l|l|}
\hline you & 'll meet & singles & you & $\begin{array}{l}\text { 're looking } \\
\text { for }\end{array}$ & $\begin{array}{l}\text {-- single men, } \\
\text { single women, local } \\
\text { singles, even a love } \\
\text { match. }\end{array}$ \\
\hline Actor & $\begin{array}{l}\text { Pr: } \\
\text { MATERIAL }\end{array}$ & Goal & Actor & $\begin{array}{l}\text { Pr: } \\
\text { MATERIAL }\end{array}$ & Goal \\
\hline
\end{tabular}


Users are invited to meet singles they are looking for. In these clauses, single people are the passive participants (Goal) of the material actions brought about by the dynamic impersonal 'you'.

The other passive participants (40.90\%) are involved mostly in Material and Relational processes. In the example below, what would be bottled by the user is the potential lover's scent, a non-human participant.

\begin{tabular}{|l|l|l|l|}
\hline whose & scent & you & 'd like to bottle, \\
\hline & Goal & Actor & Pr: MATERIAL \\
\hline
\end{tabular}

In the next two instances, Relational processes relate the human dynamic participant (who and you, respectively) to non-human passive participants (mortified and a fabulous time).

\begin{tabular}{|l|l|l|l|}
\hline who & isn't & mortified & when you make a social blunder, \\
\hline Carrier & Pr: RELATIONAL & Attribute & Circ: location: time \\
\hline
\end{tabular}

\begin{tabular}{|l|l|l|l|l|l|l|}
\hline you & 'll be getting & dates & $\begin{array}{l}\text { from } \\
\text { online } \\
\text { dating }\end{array}$ & and & having & $\begin{array}{l}\text { a } \\
\text { fabulous } \\
\text { time. }\end{array}$ \\
\hline $\begin{array}{l}\text { Actor/ } \\
\text { Carrier }\end{array}$ & $\begin{array}{l}\text { Pr: } \\
\text { MATERIAL }\end{array}$ & Goal & $\begin{array}{l}\text { Circ: } \\
\text { location: } \\
\text { place }\end{array}$ & & $\begin{array}{l}\text { Pr: } \\
\text { RELATIONAL }\end{array}$ & Attribute \\
\hline
\end{tabular}

In Table 3, the circumstances associated with the processes found in Text 1 are categorized. As can be seen, most of them are either construing the 'place' or the 'how' of the representation (36.36\% each), which accounts for almost two thirds of the occurrences (72.72\%). Since the other circumstances have been found only once, they are not relevant enough to be fully discussed. 


\begin{tabular}{|c|l|l|l|l|l|l|l|l|l|l|}
\hline \multicolumn{7}{|l|}{ CIRCUMSTANCES } \\
\cline { 2 - 10 } & $\begin{array}{l}\text { Loca- } \\
\text { tion: } \\
\text { time }\end{array}$ & $\begin{array}{l}\text { Loca- } \\
\text { tion: } \\
\text { place }\end{array}$ & Extent & Manner & Cause & $\begin{array}{l}\text { Contin- } \\
\text { gency }\end{array}$ & $\begin{array}{l}\text { Accom- } \\
\text { paniment }\end{array}$ & Role & Matter & Angle \\
\hline$\#$ & 1 & 4 & 1 & 4 & $\ldots$ & $\ldots$ & 1 & $\ldots$ & $\ldots$ & $\ldots$ \\
\hline$\%$ & $9.09 \%$ & $36.36 \%$ & $9.09 \%$ & $36.36 \%$ & $\ldots$ & $\ldots$ & $9.09 \%$ & $\ldots$ & $\ldots$ & $\ldots$ \\
\hline
\end{tabular}

Table 3 - Occurrences of circumstances in the clauses analyzed.

Out of the four occurrences of 'location: place', three construe the internet site Yahoo! Personals as the place to find love, which certainly adds to the idea that they are the service to trust when looking for a partner. See the example below:

\begin{tabular}{|l|l|l|}
\hline 'll be getting & dates & from online dating \\
\hline Pr: MATERIAL & Goal & Circ: location: place \\
\hline
\end{tabular}

The other occurrence refers to a coffeehouse or gas station, but the text does so only to argue later that this would be a less productive option when looking for a new partner.

\begin{tabular}{|c|c|c|c|c|c|c|}
\hline You & still & might meet & \multicolumn{2}{|c|}{ the love of your life } & \multicolumn{2}{|c|}{ at a coffeehouse or gas station. } \\
\hline Actor & & $\begin{array}{l}\text { Pr: } \\
\text { MATERIAL }\end{array}$ & \multicolumn{2}{|l|}{ Goal } & \multicolumn{2}{|l|}{ Circ: location: place } \\
\hline But & \multicolumn{2}{|c|}{$\begin{array}{l}\text { with Yahoo! } \\
\text { Personals, }\end{array}$} & \multicolumn{3}{|c|}{$\begin{array}{l}\text { instead of sitting around waiting for that to } \\
\text { happen, }\end{array}$} & you \\
\hline & \multicolumn{2}{|c|}{ Circ: manner } & \multicolumn{3}{|c|}{ Circ: accompaniment: additive } & $\begin{array}{l}\text { Actor/ } \\
\text { Carrier }\end{array}$ \\
\hline \multicolumn{2}{|c|}{ 'll be getting } & dates & $\begin{array}{l}\text { from online } \\
\text { dating }\end{array}$ & and & having & $\begin{array}{l}\text { a fabulous } \\
\text { time. }\end{array}$ \\
\hline \multicolumn{2}{|c|}{ Pr: MATERIAL } & Goal & $\begin{array}{l}\text { Circ: location: } \\
\text { place }\end{array}$ & & Pr: RELATIONAL & Attribute \\
\hline
\end{tabular}


Having discussed the results of the transitivity analysis and the patterns that they reveal in regard to the representations in the text, I now extend this discussion to include considerations about social identities, ideologies, power and hegemonic relations so that the text can be associated with the social practices within which it is construed.

In the first sentence You deserve a matchmaker to find love, it can already be seen that the broader social identities represented in this text: someone who is looking for love and another who supposedly can find it. One may say that these identities are expected to be found in a text about a matchmaking service; however, a critical reader needs to address the underlying assumptions in the text "from a resistant or subversive point of view" (Heberle, 2000: 121).

Therefore, by understanding the discursive representations made through specific linguistic choices, people "may become apt to have a more proactive attitude in the discursive community to which they belong" [my translation] (Bezerra, 2003: 10). Then, a first question to be asked is why the search for another person needs to be limited to love. It seems that, if you are single, the obvious reason why you would use an online matchmaking service is to find a steady relationship. Of course, that is not necessarily the case.

Another aspect in the text regarding social identities is the assumption that if you are single, it is because you haven't put yourself out there. The text seems to neglect the fact that singlehood may be a personal choice, and not something that happens to you because you haven't been open to finding a partner. One can see, then, that in subtle ways the identity that is created in the text is that of people who want to find love, but, in order to avoid being single any longer, they have to make the effort of putting themselves out there, which is to be achieved by creating a profile on Yahoo! Personals. Arguably, this social identity may fit a number of people who would seek this kind of service. However, there are other people with different objectives who could also create a profile on this webpage. They could be, for instance, single, married or divorced people looking for friendship or sex only. 
According to Fairclough (1989: 85), "ideology is most effective when its workings are least visible", hence the importance of understanding what lies beneath the linguistic construal of the text under analysis. As previously discussed, in Text 1, certain identities were given prominence to the detriment of others, which shows the writer's ideological stance. Thus, the work of the critical analyst should be precisely to investigate how language use is informed by certain ideological and political objectives. In other words, discourse (language use in context) needs to be examined and revealed in its corresponding social practice, as it is "developed in specific social contexts, and in ways which are appropriate to the interests of social actors in these contexts" (van Leeuwen, 2005: 94).

Hence, the discussion of the ideologies that inform this text may contribute to understanding the values and beliefs that need to be challenged in case they are used, for example, to sustain unequal power relations, especially for the fact that "every text is an instrument of communication set in a social context, influencing and, at the same time, being influenced by it" [my translation] (Caldas-Coulthard, 2008: 36). One ideology that is present in Text 1 was already mentioned: the one that single people are all looking to find partners, which is also discussed by Bezerra (2008: 26) when he states that the "pursuit of marriage is not only motivated by procreational needs, but also by a growing demand for a shared life".

Another ideological proposition is the long-standing belief that there is that one special person for everyone, which can be seen in the sentence you can find that unique person who gets what you're all about. This idea is further extended by the appeal to an idealized partner who says what you were about to say, who isn't mortified when you make a social blunder, whose scent you'd like to bottle, and whose smile you'd like to wake up to every day. These sentences create the image of a perfect partner, the one who is worth the trouble of making a profile on their dating site. In such case, you may even be reasonably comfortable with your single life, but, after reading this description of such a dreamy person, you might as well just try and see if that special someone is really out there. 
Importantly, discourse may not only be used to sustain the status quo, it can also be used to challenge it, which can be observed in the possibility of varied dating scenarios stated in the sentence $B y$ taking a personal approach to personal ads, you can find a date and find singles for Christian dating, Jewish dating, Asian dating, black dating, gay dating, or senior dating. Here, there are alternatives for people of different religious affiliations, origins, ethnical background and sexual orientation, which is certainly something to be acknowledged as positive, especially since CDA can be seen as "a form of intervention in social practice and social relationships" (Fairclough \& Wodak, 1997: 258). Thus, through the use of language in this specific social practice, different options are being offered to different people other than the hitherto hegemonic white, heterosexual, middle-class citizens. And that possibility might be seen as an instance of transformation, which gives rise to the discussion of another notion in the critical discourse analysis of Text 1 - that of power.

Regarding power relations, there are some points to be discussed in the text. Returning to the concept of changed relationships of intimacy, according to which people trust more in abstract systems than in personal contacts, it is interesting to notice that, in Text 1 , the abstract system of an online dating site is portrayed as being dedicated, a characteristic proper to people, which seems to work towards compensating the lack of "intimacy which personal trust relations offer" (Giddens, 1991: 114). This way, Yahoo! Personals is represented as being closer to its users, offering a more personal service, which helps in getting people's trust that the service advertised by the site will be effectively delivered. So, by creating this closer relationship, they are trying to forge an idea of equality, which is only ideal, since the terms of the service are all previously stated, leaving the user with the only choice of either accepting it or not.

Another instance of unequal power relations can be found in the sentence That's why we give you an audience filled with local singles. Understandably, the audience has to be made available for search by the site; however, what has to be observed is how this is construed by the language choices in the text. The way it is done in Text 1, users 
are placed in the position of receivers of an audience filled with local singles, so they take no active role in it, which construes the internet website as doing all the hard initial work of bringing a great number of people together for users only to choose from.

However, I have also noticed that this initial passive role is softened by placing users also as those who will do something to find a partner, by using the tools to find and meet single women and single men, and lots of features that help you find your love match. Therefore, users are also given the chance to take a more active role in finding their partners. Nevertheless, what they will use to find them is also provided by the site (tools and features), which places Yahoo! Personals in a privileged position after all.

In the discussion of power relations, it is important to highlight that "much power in society (...) is not coercive, but rather mental" (van Dijk, 1997: 17). The present analysis has demonstrated that most ideologies and power relations are created by the subtle and purposeful use of language in context. It is precisely this possibility of making people do what one wants them to do, but having them believe it is also what they want, through the use of persuasive discourse, that characterizes the main objective of hegemonic struggles. In other words, "the term hegemony is often used to refer to social power: hegemonic power makes people act as if it were natural, normal, or simply a consensus" (van Dijk, 1997: 19).

Thus, when one reads in Text 1 that with Yahoo! Personals, instead of sitting around waiting for that to happen, you'll be getting dates from online dating and having a fabulous time, it is not easy to notice, at first, the hegemonic power being exerted. This sentence might simply seem to mean that, in order to find a partner, people have to get up and do something about it. However, underlying this call for action lies an increasing placement of abstract systems (Giddens, 1991) as more reliable resources for matchmaking than the more traditional choice of, for instance, going out with friends to a coffeehouse. 


\section{Final Remarks}

This paper has aimed to demonstrate how language can be used to create particular representations of the world as well as how these representations may serve specific social and institutional agendas, thus enabling us to reveal "if they foster emancipation or just maintain the status quo" (Bezerra, 2011). That is one of the main contributions that SFG, especially in terms of its system of transitivity (Halliday \& Matthiessen, 2004), can make to the critical discourse analysis of the myriad of texts that permeate contemporary society.

Textual analysis has shown that Text 1 construes dynamic participants as the general public (single men and women) by use of the impersonal 'you'. Passive participants are mostly human, which is expected, since the text is about creating social bonds - finding a partner. These dynamic and passive participants, in turn, are vastly involved in processes that bring about change in the material world - and that change is about finding the perfect partner for singles out there. Discursive analysis has revealed that, even though Yahoo! Personals seems to be represented in an equal relation of power with users, there is an asymmetrical distribution of power disguised by the apparent dynamic role assigned to potential users.

Therefore, as previously argued, the concepts and categories described in SFG and used in the present study have been useful when carrying out analysis at the textual level. That theoretically principled analysis is, in turn, strengthened by using notions from CDA that help the analyst address the interrelation between the text and its corresponding social processes, which helps unveil the power relations and ideologies that are being (re)enforced.

Finally, along with the placement of abstract systems as more reliable sources of relationships of intimacy in contemporary society (Giddens, 1991), these results urge us to ask whose interests this displacement might be serving, especially in our modern era, where the media, controlled by powerful corporations, are occupying an ever increasing space in people's professional and personal lives. 


\section{References}

Bezerra, F. O gênero textual "Mensagem ao Consumidor" nas contas de energia elétrica da SAELPA: A relação discursiva entre as partes.Letr@Viv@, 5(1): 9-26, 2003.

. 'SEX AND THE CITY': An investigation of women's image in Carrie Bradshaw's discourse as narrator. Dissertação de Mestrado. Pós-graduação em Inglês. Universidade Federal de Santa Catarina, Florianópolis, SC, 2008.

. A imagem feminina em Sex and the City: Uma análise de transitividade da narração. Revista Investigações, 24(2): 103-133, 2011.

Bloor, T.; Bloor, M. The functional analysis of English. London/NY: Arnold, 1995.

Caldas-Coulthard, C. R. News as social practice: A study in critical discourse analysis. Florianópolis: Pós-graduação em Inglês/UFSC (ARES - Advanced Research in English Series), 1997.

. Da análise do discurso à análise crítica do discurso: Introduzindo conceitos. In: Caldas-Coulthard, C. R. \& Scliar-Cabral, L. (Orgs.) Desvendando discursos: Conceitos básicos. Florianópolis: Ed. da UFSC, 2008, p. 19-44.

Chouliaraki, L.; Fairclough, N. Discourse in late modernity: Rethinking critical discourse analysis. Cambridge: Polity Press, 1999.

Fairclough, N. Language and power. London: Longman, 1989.

Fairclough, N.; Wodak, R. Critical discourse analysis. In: van Dijk, T. A. (Ed.) Discourse as social interaction. London; Thousand Oaks; New Delhi: Sage, 1997, p. 258-84.

Giddens, A. The consequences of modernity. Cambridge: Polity Press, 1991.

Halliday, M.A.K. The notion of "context" in language education. In: Ghadessy, M. (Ed.) Text and context in functional linguistics. Amsterdam: John Benjamins, 1999, p. 1-24.

Halliday, M.A.K; Matthiessen, C. M.I.M.. An introduction to functional grammar. 3. ed. London: Hodder Arnold, 2004. 
Hasan, R. Linguistics, language and verbal art. Melbourne: Deakin University Press, 1985.

Heberle, V. An investigation of textual and contextual parameters in editorials of women's magazines. Tese de Doutorado. Pós-graduação em Inglês. Universidade Federal de Santa Catarina, Florianópolis, SC, 1997.

. Critical reading: Integrating principles of critical discourse analysis and gender studies. Ilha do Desterro, 38: 115-138, 2000.

Martin, J. R. Language, register and genre. In: Burns, A. \& Coffin, C. (Eds.) English in a global context: A reader. London: Routledge, 2001, p. 149-66.

Martin, J. R.; Matthiessen, C. M.I.M.; Painter, C. Deploying functional grammar. Beijing: The Commercial Press, 2010.

Ravelli, L. Getting started with functional analysis of texts. In: Unsworth, L. (Ed.) Researching language in schools and communities. Functional linguistics perspectives. London and Washington: Cassell, 2000, p. 27-64.

van Dijk, T. A. Discourse as interaction in society. In: van Dijk, T. A. (Ed.) Discourse as social interaction. London; Thousand Oaks; New Delhi: Sage, 1997, p. 1-37.

van Leeuwen, T. Introducing social semiotics. London/New York: Routledge, 2005. 